\title{
Potential Information Media for Village Petang based on Video to Promote Tourism Village
}

\author{
Agus Aan Jiwa Permana \\ Universitas Pendidikan Ganesha \\ Email:agus.aan@undiksha.ac.id
}

Gede Yoga Sucipta

Universitas Pendidikan Ganesha Email:yogagates12@gmail.com

\begin{abstract}
This paper provides a template for preparing papers for electronic production of the Journal of Education Technology. A This study aims to create a storyboard, and implement a video entitled Media Information Potential Tourism Village District Petang Badung Regency. The method used in making the Potential Information Media for Tourism Village in the District of Petang in Badung Regency is Non Linear (Computer or Digital), where this method uses tools such as a computer as an editing tool so that the editing process becomes more maximal. Experiments conducted by the author whether the video has gone according to the storyboard, Video Media Information Potential Tourism Village District Petang Badung District lasts 8 minutes. Implementation of the Material Expert Test to see whether the data and content applied to the video are correct with existing data or not. $85 \%$ of the results obtained from the Expert Test Material means that the video is Very Good to use. Implementation is carried out in the Media Expert Test to see whether the video can be used or not. $72.25 \%$ results means the video is good to use. The benefit of the Potential Information Village for Tourism Village in Petang Sub-District, Badung Regency is that the community can know about Petang Sub-district and the tourism potential contained in the Petang District in Badung Regency.
\end{abstract}

Keywords: Media, District, Badung, Video

\section{Introduction}

The existence of a tourism village is currently emerging and developing based on its potential, as well as the down-and-down activities that are leading in the village and how the village party informs the potential of the area to the wider community. Then it takes the ability, knowledge, and creativity in exploring the potential of the village. According to my observations, several things or activities that can make a village become a tourist village include: crafts, arts and culture, natural beauty, agriculture, relics of certain guardians / figures. Bali is one of the islands in Indonesia which has a high tourism existence. Bali has a lot of tourism potential that is growing with the number of local and foreign visitors. Each district in Bali has its own tourism potential. Petang is one of the districts in Bali that has quite high tourism potential.

Each village in the Petang sub-district has its own tourist attraction, but not many tourists know about the tourism that is owned by the Petang District. Therefore, it is necessary to make a Promotion Video for Petang subdistrict which aims to promote the tourism excellence of Petang sub-district to local and long-distance tourists. Tetang is a sub-district that produces a lot of natural food and many natural attractions. Natural food and nature tourism produced by each village are certainly different and various types and have their own characteristics. Evening has 7 villages that have different tourism potentials. Villages in the evening include Sulangai Village, Plaga Village, BelOX Village, Petang Village, Getasan Village, Pangsan Village, and Carangsari Village. Exploring the village's potential for promotion and strengthening tourist destinations, culture, and food produced, is intended to further advance the villages. village in Petang sub-district, Badung, Bali.

\section{Research Methods}

The development of promotional videos is very important to introduce products to consumers so that they can be more widely introduced (Goenawan et al., 2013), (Permana, et al., 2017). In the video development process, there are several stages, namely the Preparation Stage, the Recording Stage, the Editing Stage, then the Trial, if it fails then return to the recording or editing stage and if it is not necessary then the media has been declared to have been developed.

\section{Video}

Saputra (2017) says that video is a technology for capturing, recording, processing, transmitting and rearranging moving images. Video is a combination of images that are coupled and moving, called FPS (Frame Rate per Second). Video is a medium to inform a form of moving pictures and audio and has a clear purpose and flow. 


\section{Promotional Video}

Promotional Video is a form of information media that aims to notify a matter in the form of video and audio that focuses on a product, views, potential, etc. (Ardianto, 2016).

\section{Tourism Village}

Tourism village is an area that has a tourism existence, rural natural beauty, unique and preserved cultural diversity, natural food products, and tourism objects to improve the village economy and develop or advance the village (Fennel, 2016).

\section{Video Development Process}

Storyboard

Storyboards are ideas or ideas that are illustrated to make the process easier to do. Storyboard is the initial design of something to be done, defines the plot of the story, and creates an initial shoot. Storyboards can make it easier to determine how the program or story will be created using the frameworks described in the process and the flow that is designed in this way (Prasetyo, 2015). After creating the Storyboard, the video creation process begins. The stages can be seen in Figure 1.

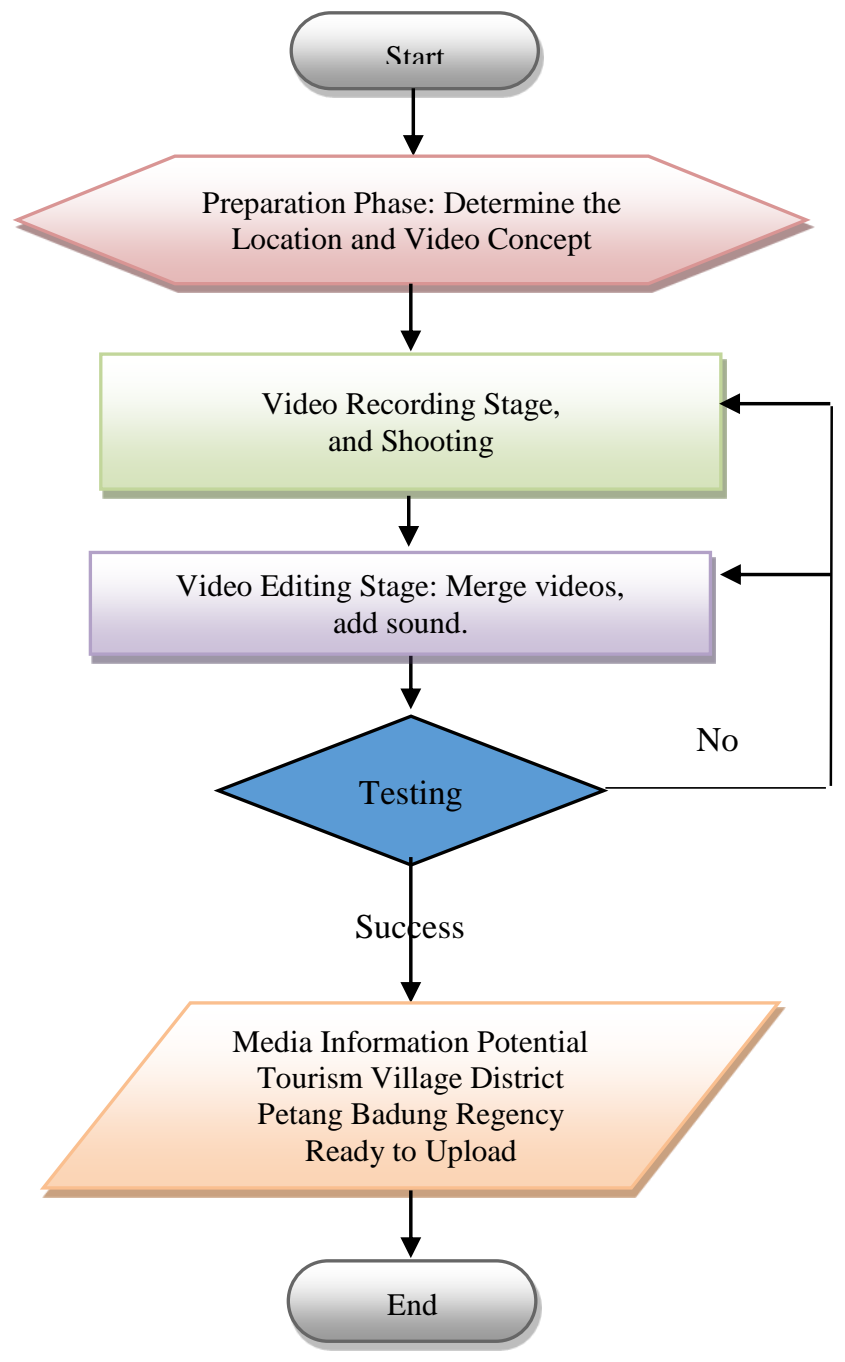

\section{Preparation phase}

Figure 1. The video creation process

The preparation phase is the initial stage in the making of a promotional video for Media Information on Potential Tourism Village of Petang District, Badung Regency. In this preparation stage, determining the location where the video will be taken, story ideas, then stories and scenarios will be made to facilitate the process of making videos in order to get maximum results, in order, and use the time not too long in the process of taking video. The concept or idea will be written to the Storyboard to make it easier for others to know the idea to be made. Storyboard that tells a sequence of stories from the video, in the story recorded scenes, narration, and duration. 


\section{Recording Stage}

Recording stage is the process of copying an image or sound using a recording device (Maryati and Purnama, 2013). The process of transferring video files recorded on the camera to a computer using a connecting device called USB, to be stored in a storage room on the computer which will be processed and edited. Before recording, you must create a storyboard in advance to facilitate the video recording process, determine the right point of view to get a good video.

\section{Editing Stage}

Editing is the activity of cutting up long images, connecting pieces of pictures that tell a story (have a sequence) in the specified duration, and ready to be aired in time (Wahyudi, J.B, 2004). The software used for the editing process is Adobe Premier software, where Adobe Premier is a software that is very commonly used by TV stations, production houses, YouTuber, because it is very easy to learn and has many effects. Adobe After Effect is used to add effects to videos. Adobe Audition is software for changing sound. Used to change sound or manage music with the features available in this software (Sari, 2018).

\section{Test Phase Media Expert and Material Expert}

Expert Test Stage is the stage to check the video if it is in accordance with the storyboard that is made, check the sound on the video to match the video. After that, it will receive input so the video results are more optimal. Video improvements produce videos that are worth promoting. Videos that have passed the media expert testing stage will proceed to the publication stage (Rusti, 2012). Test Phase Media Expert and Material Expert, using a questionnaire with the assessment video promotion to the Expert. Includes a promotional video display whether it is within the standard of manufacture as well as original data from research observations. The questionnaire given contained potential for tourism as well as information from various villages in the Petang District of Badung Regency. An individual figure / person who knows in detail about the villages in Petang Sub-District, Badung Regency is assessed.

\section{Validity Test Results}

Validity test is conducted on the video to determine the suitability of the contents of the video content. Validity Test is conducted by media experts and 2 material experts. The formula looks for the percentage of validity test results (Sugiyono, 2008). The formulas used to find percentages are as follows:

\section{$\mathbf{P}=\sum$ (Weight $\mathrm{x}$ Number of criteria) $/ \mathbf{N}$}

Information :

$$
\begin{aligned}
& \mathrm{P}=\text { percentage } \\
& \mathrm{N}=\text { Maximum value }
\end{aligned}
$$

\section{Video Evaluation Criteria}

The weights for the questionnaire equation are as follows and criteria of value presentase show on Table 1.

- Very Good (SB) : 4

- Good (B) :3

- Less (K) :2

- Very Poor (SK) : 1

Table 1. Percentage Criteria

\begin{tabular}{ll}
\hline Persentase Score Test & Description \\
\hline $\mathbf{0 - 2 5 \%}$ & Very Poor \\
$\mathbf{2 5 - 5 0 \%}$ & Less \\
$\mathbf{5 0 - 7 5 \%}$ & Good \\
$\mathbf{7 5 - 1 0 0 \%}$ & Very Good \\
\hline
\end{tabular}

\section{Publication Stage}

The publication stage which is the final process of making a promotional video for Media Information on Tourism Village Potential in Petang District, Badung Regency. Videos produced from the editing and testing stages of media experts will be uploaded to Youtube. Youtube has the highest attraction in the world with the highest visitors in the world accessing YouTube 1.5 billion every month. On this basis, Youtube is used as a promotional medium of the Tourism Village Potential Information Village in Petang District, Badung Regency.

With users in almost all countries in the world that are on Youtube because of spreading information very quickly and well it is hoped to be able to introduce villages in Petang sub-district and see the tourism potential 
generated from villages in Petang District. The results of the implementation made are based on Storyboard which can be seen as Table 2 .

Table 2. Storyboard Video

\section{No Description}

1. Opening. The results of the implementation can be seen as in Figure 2.

2. Displaying a video with the text "Video Promotion District Petang, Badung Regency". The results of the implementation can be seen as in Figure 3.

3. Displaying Video Promotion Media Information on Potential Tourism Village in Petang District, Badung Regency. The results of the implementation can be seen as in Figure 4. Narration "Badung is one of the regencies in Bali. Badung is very rich in tourism potential and natural products produced, it can be proven by the many tourist destinations produced. Evening, is one of the Districts in Badung Regency. Many natural tourism destinations are produced by Petang District, and natural products can be exported. Petang Subdistrict has 7 villages including Sulangai Village, Plaga Village, Belok Sidan Village, Petang Village, Getasan Village, Pangsan Village and Carangsari Village, each village has different tourism potential. Culture and customs are also still preserved until now. "

4. Displaying the text "Sulangai Village".

Interview by the resource person, namely the Sulangai Village Head / Deputy Village Head /

Community Figure.

5. Displaying the text "Village Plaga".

6. Interview by the resource person, namely the Plaga Village Head / Deputy Village Head / Community Figure.

7. Displaying the text "Village of Belok Sidan".

8. Interview by the resource persons, namely the Village Head of Belok / Deputy Village Head / Community Figure.

9. Displaying the text "Village of the Evening"

10. Interview by the resource persons, namely the Village Head of Petang / Deputy Village Head / Community Figure.

11. Displaying the Text "Getasan Village".

12. Interview by the interviewees, namely the Getasan Village Head / Deputy Village Head / Community Figure.

13. Displaying Text "Pangsan Village".

14. Interview by the resource persons, namely the Pangsan Village Head / Deputy Village Head / Community Figure.

15. Displaying Text "Carangsari Village".

16. Interview by the resource person, namely the Carangsari Village Head / Deputy Village Head / Community Figure.

17. Display the video with the Text "Thank's For Watching".

18. Displaying Text "Final Project Promotion Video for Information Media in Petang District, Badung Regency".

19. Displaying Text Thank you

20. Displaying the Undiksha Text and logo and Petang District "This Promotional Video can be held because of the collaboration: (Logo and text)".

21. Credit.

The results of the implementation of the storyboard can be displayed as follows. Figure 2. Displays the Opening Timelapse from night to morning. Figure 3. Displaying the Text "Video Promotion District Petang, Badung Regency". Figure 4. Displaying a video of the natural potential of the villages of Petang District, Badung Regency. 


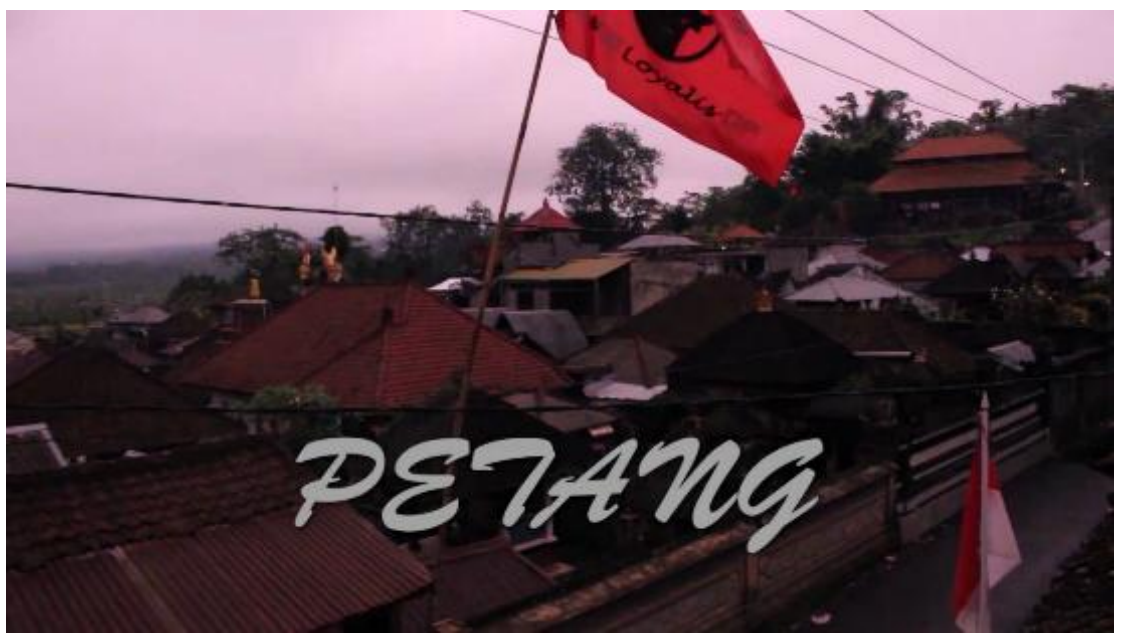

Figure 2. Opening

\section{Video Promosi Kecamatan Petang Kabupaten Badung}

Figure 3. Displaying a video with the text



Figure 4. Displaying a video of the natural potential

Figure 5. Displaying Text for each village in Petang sub-district, starting with Sulangai Village. Text for each village in Petang sub-district, starting with Sulangai Village. Figure 6. Displays the interview by the resource person, namely the Village Head of Beloksidan / Deputy Village Head / Community Figure. In addition to the village of beloxidants, all village leaders in the evening sub-district were also interviewed such as Sulangai, Plaga, Getasan, Pangsan, Carangsari Villages. Then Figure 7. Displays the Text "Final Project Video Promotion Media Information Petang District Badung District". At the end of the video shows a credit that can be seen as Figure 8. 


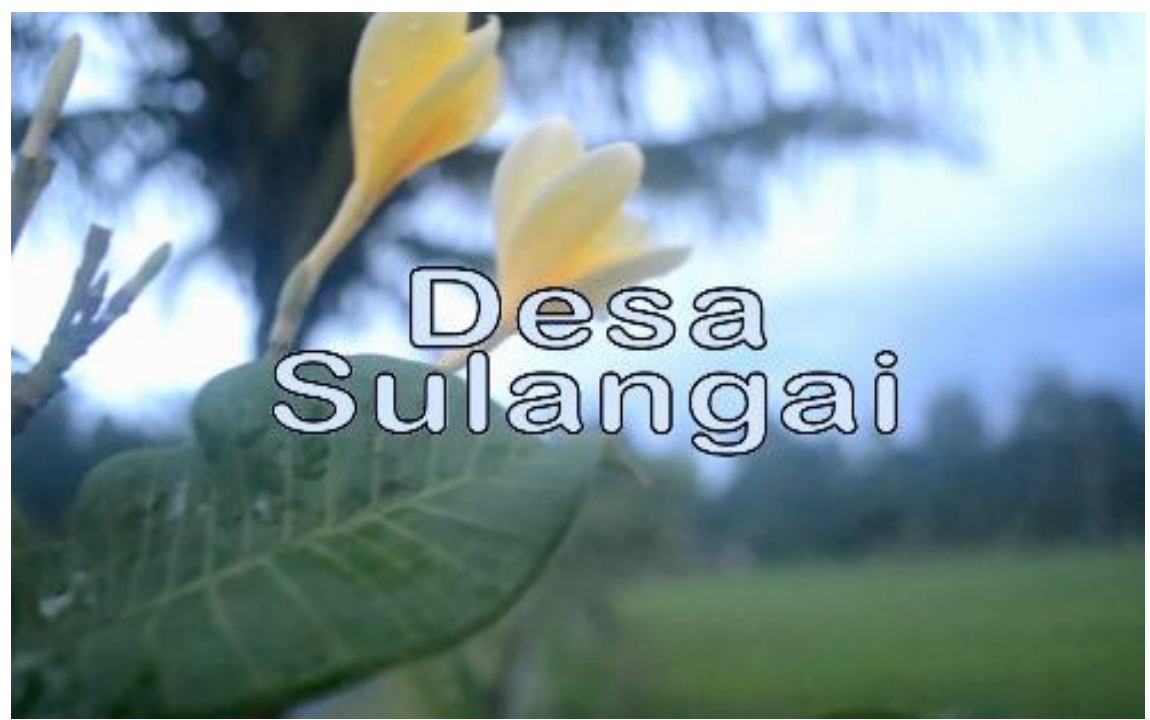

Figure 5. Displaying Sulangai Village

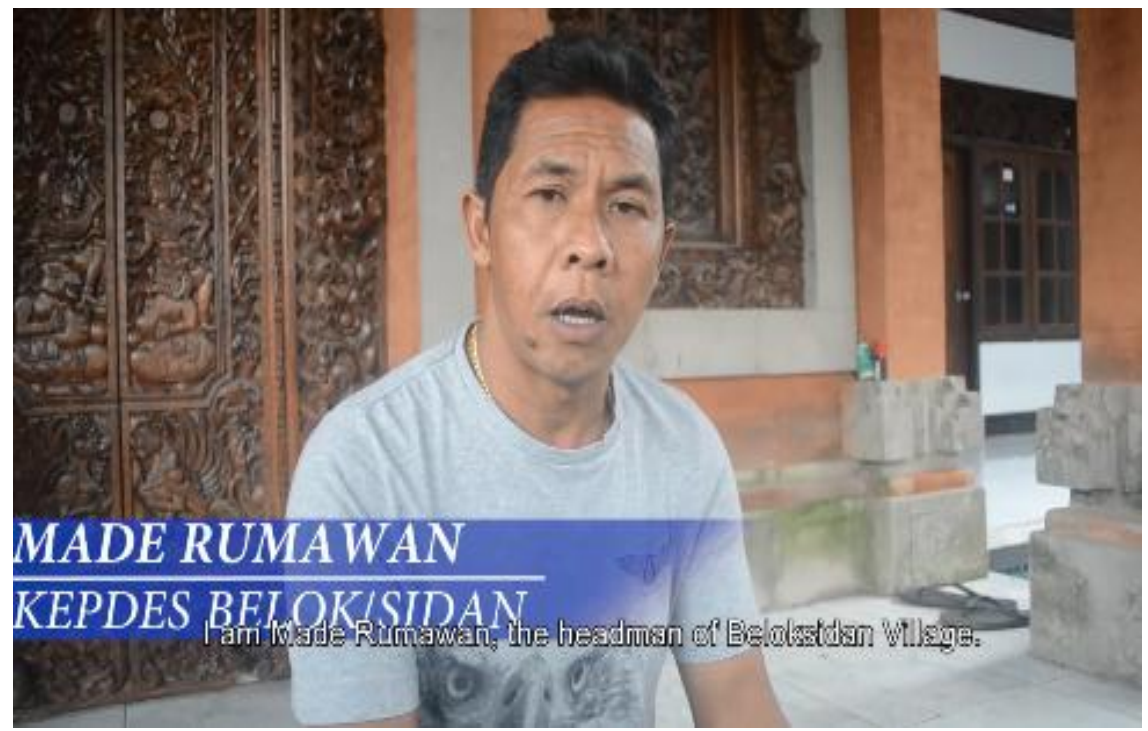

Figure 6. Displays the interview with public figure

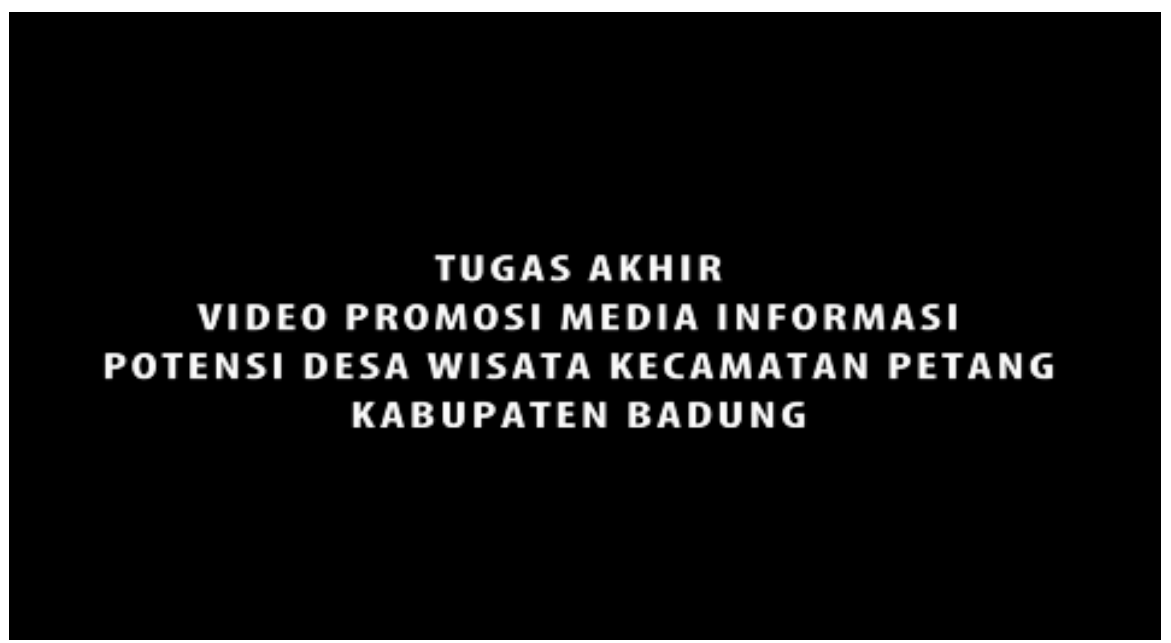

Figure 7. Show Text Final Project 


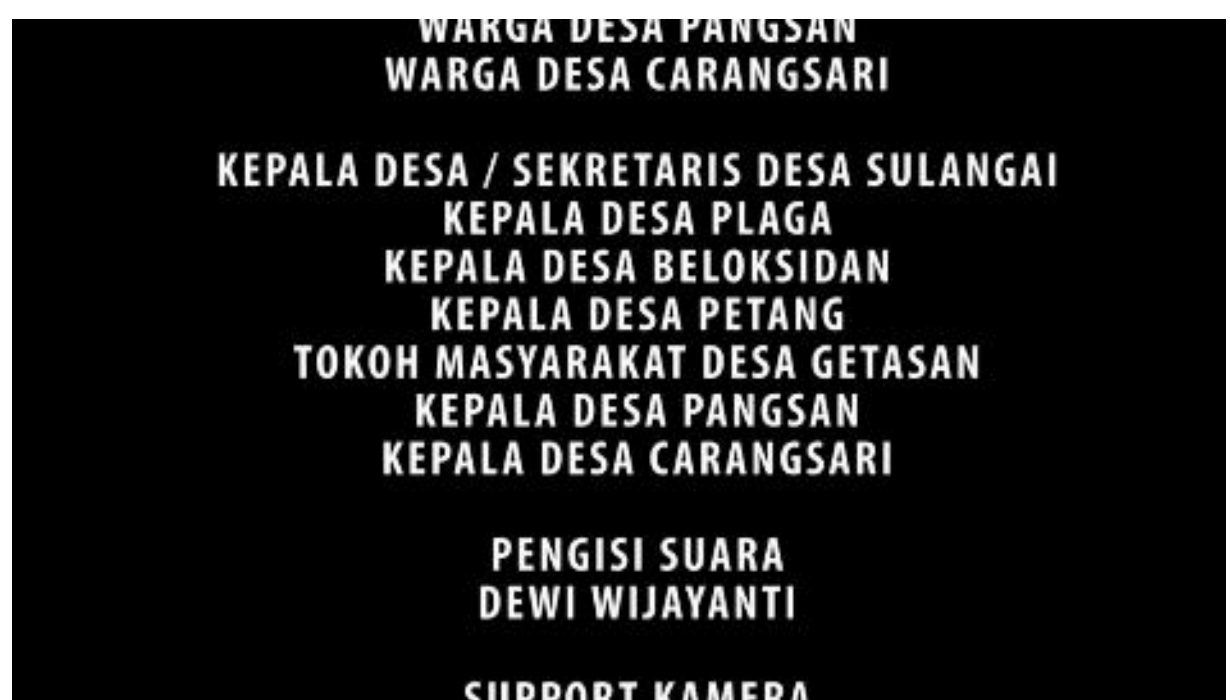

Figure 8. Credit and Thanks to all

\section{Conclusions}

Media Information Video Promotion of Petang District Badung District can be used as a media of information and promotional media that can provide an explanation of the general picture of the Petang District of Badung Regency.

In the process of making this video using effects editing, video editing and sound editing. In producing a Video Promotion Media Information for Petang Sub-District, Badung Regency, a design that includes storyboard design, audio video editing is needed, so that the production and publication process runs as expected. This video was edited with professional editing techniques and all stages of the video are in accordance with the plan on the storyboard and rendered with 3 hours to produce HD quality video with the Mp4 video format.

Media Information Video Promotion Petang Subdistrict Badung Regency that has been implemented is continued to be tested involving two examiners. According to Expert Expert I expert examiners, the results obtained $85 \%$, so it can be concluded that the video produced in general has been "Very Good" and is ready to be used as a promotional media in the District of Petang, Badung Regency towards the tourist village. According to the Media Expert Test II, 72.25\% results were obtained, which means the resulting video was included in the "Good" category and was ready to be used to promote Petang District in Badung Regency. The evaluation criteria in the range used by experts can be seen as in Table 1.

Media Information Video Promotion of Petang District Badung Regency is expected to be able to help advance the tourism potential in Petang District Badung Regency and can add tourist destinations and natural exports. Weaknesses in the video lies in the video clarity, video display, dubbing suitability, and harmony of music that still needs to be improved again.

The next research development that can be done on the Promotion Video Information Media in Petang Sub-District, Badung Regency is by creating a Website as a Web-based information media, and other development that can be done is making a QR guide for Un-guide or mobile guides where tourists can use applications that are made to indicate the place and direction of tourist sites using the QR code

\section{Acknowledgement}

Thanks are addressed to God Almighty, as well as Information Management Students 2016 generation who have taken the time to help the process of making Video Information Media Promotion Petang District Badung District. Then to all employees and lecturers of Information Management, employees and staff in the Faculty of Engineering and Vocational Undiksha who have provided a lot of support so that the Media Information Video Promotion District Petang Badung can be resolved.

\section{References}

Ardianto, H., 2016, Jurnal yang berjudul "Perancangan Video Promosi "Mengenal Sejarah di atas Rel”. Tersedia pada http://repository.uksw.edu/bitstream/123456789/10465/2/T1_692011041_Ful\%20Text.pdf.

Fennel, 2016. Teori Desa Wisata, http://desawisatakotagede.blogspot.com/2016/01/teori-desa-wisata.html? $m=1$. Maryati dan Purnama, 2013, Produksi Video Klip Multiplek Lagu, https://ijns.org/journal/index.php/ speed/article/download/1064/1052.

Permana, A.A.J., Kertiasih, N.K., Budhayasa, I.P,2017, Jurnal yang berjudul "Video Profil Sebagai Sarana Promosi Efektif Dalam Menunjang Eksistensi Program Studi Manajemen Informatika", https://ejournal.undiksha.ac.id/index.php/JST/article/view/10705. 
Rusti, S.C, Penelitian Pengembangan (Research and Development/ R\&D), http://shilviacitrarusti.blogspot.com /2012/04/penelitian-pengembangan-r.html.

Saputra, A.P.H, 2011, Pengertian Video, http://putraarifxmmb.blogspot.com/2011/02/pengertian-video.html. Sari, K.N.W., Tugas Akhir yang berjudul "Video Promosi Desa Bali Aga SCTP".

Sugiyono, 2008, Uji Validitas, http://repository.upi.edu/5830/6/S_PEK_0906478_Chapter3.pdf

Wahyudi, J.B, 2004, Pengertian Editing, http://sieditor.blogspot.com/2012/03/pengertian-editing.html 